Edith Cowan University

Research Online

Research outputs 2012

$1-1-2012$

\title{
Graffiti Offenders' Patterns of Desistance from, and Persistence in, Crime: New Insights into Reducing Recidivist Offending
}

Myra Taylor

Umneea Khan

Follow this and additional works at: https://ro.ecu.edu.au/ecuworks2012

Part of the Social and Behavioral Sciences Commons

This is an Author's Accepted Manuscript of: Taylor, M. F., \& Khan, U. (2012). Graffiti Offenders' Patterns of Desistance from, and Persistence in, Crime: New Insights into Reducing Recidivist Offending. The Police Journal, 85(0), 5-28. Copyright 2012 The Police Journal. Reprinted by permission of SAGE Publications here This Journal Article is posted at Research Online. https://ro.ecu.edu.au/ecuworks2012/300 


\title{
GRAFFITI OFFENDERS' PATTERNS OF DESISTANCE FROM, AND PERSISTENCE IN, CRIME: NEW INSIGHTS INTO REDUCING RECIDIVIST OFFENDING
}

\begin{abstract}
While graffiti is a gateway crime towards more serious criminal offending, little is known about graffitists' patterns of desistance from, and persistence in, crime. This paper addresses this knowledge shortfall through an examination of the Western Australian Police Information Management System (IMS) database for three age-groups (i.e. preteens, adolescents, adults) and three categories of graffiti offenders (Early Desisters, Limited Persisters, Chronic Persisters). Descriptive and chi-squared statistics reveal that: i) nearly three-quarters of all of the 667 preteen, adolescent and adult graffiti offenders desisted from further offending after their first or second contact with police; ii) the mainly adolescent cohort of Limited Persister offenders account for the majority of all recorded violent crime; and c) most graffiti offenders are processed through the court system for both their graffiti and non-graffitirelated offences. The implications for designing recidivist intervention programmes that target offenders at the different stages of their offending are discussed.
\end{abstract}

Keywords: graffiti; crime; police; resilience building; Early Desisters, Limited Persisters, Chronic Persisters; preteen, adolescent, adult offenders

While few juveniles aged $<18$ years progress through childhood, into adolescence, and on to adulthood without some minor dalliance in crime, it is estimated that only a very small (but increasing) percentage of juveniles (5-10\%) actually constitute the cohort of seasoned offenders who collectively account for $55 \%$ of all recorded juvenile crime (Henry et al., 1996; Cottle et al., 2001; Loeber et al., 2001; Muncie, 2004; Roe \& Ashe, 2008). Despite recognising that some juvenile offenders are 
more prolific than others, it is surprising how little research effort to date has been directed towards understanding why many juveniles desist from further offending after just one or two dalliances in crime while others persist with their offending. Although it is impossible to accurately measure criminal desistance/persistence it is generally accepted that such measures as utilising police databases are acceptable proxies for determining patterns of offending (Richards, 2011). Hence, the presented examination of the Western Australian Police Information Management System (IMS) offender dataset provides new insights into the crime desistance/persistence patterns of a common group of entrant offenders, namely graffitists.

\section{Desistant and persistent patterns of offending}

Much of the existing body of juvenile desistance/persistence research literature has concentrated on unravelling the underlying causes of offending. As a consequence, four main offending risk factor categories have been identified, namely, static personal risk factors (e.g. age at time of first conviction, male gender, intelligence quotient, neuropsychological characteristics), static environmental factors (e.g. low socioeconomic status, parental neglect, parental conflict, institutional maltreatment, care and protection orders, physical/sexual abuse), dynamic personal risk factors (e.g. psychopathological conduct/ attentional disorders, antisocial personality traits, substance abuse), and dynamic environmental risk factors (e.g. poor social environment, poor economic circumstance, neighbourhood disadvantage, membership of a criminogenic family, family instability, association with delinquent peers). Moreover, it is also recognised that when these factors co-occur then juveniles are more disposed towards recidivist offending (Cottle et al., 2001; Palermo, 2009; Mulder et al., 2010; 2011).

Static risk factors differ from dynamic risk factors insofar as they are those factors that cannot be changed in a person's life, while dynamic factors are those that can be altered through intervention. For example, the static risk factor 'commencement age of offending' is argued to be one of the strongest individual predictors of whether a novice offender will go on to become part of the very small cohort of highly prolific offenders who start offending in childhood and persist with their offending through adolescence/adulthood, or whether they will form part of the much larger, but less prolific, cohort of juvenile offenders whose span of offending is limited to adolescence (Moffitt, 1993). The childhood early-onset life-course persistent pattern 
offender (LCP) usually has multiple static and dynamic high-risk factors (e.g., severe family hardship/dysfunction, hyperactivity, neuropsychological deficits, low self-control, social isolation) and, because of the persistence and severity of their offending, this group are considered to be the most problematic for society (Mulder et al., 2011), while their adolescent limited (AL) pattern offending counterparts are believed to be motivated to engage in criminal acts of antisociality by the teenage desire of establishing a non-conforming social identity (Henry et al., 1996; Carroll et al., 2009; Taylor et al., 2010; Taylor, 2012). However, given that this teenage identity establishment desire is the providence of adolescence, AL offenders exiting their teens are thought to lack the compunction to continue with their offending into adulthood and so are deemed to 'age out of crime' (Gottfredson \& Hirschi, 1990; Moffitt, 1993; 2003; 2006; Stuewig, 2000; Odgers et al., 2007; J-F, 2010). Furthermore, the crimes that AL pattern offenders commit tend to be less frequent, less violent and more situational in nature (Carroll et al., 2009).

It is reasoned that LCP offenders, with their multiple static and dynamic risk factors, have very different personal and environmental needs than those of their AL offending counterparts. As such, there is a growing need for research studies (such as the present one) to tease out different age-related desistance/ persistence patterns of offending. Complicating such research endeavours is the reality that the static and dynamic factors that influence desistance/persistence patterns of offending can vary from individual to individual and from context to context (J-F, 2010), a further complication being that no clear definition exists as to what constitutes criminal desistance or persistence. More surprising still is that there is no academic consensus on how long an individual needs to have stopped offending before they can be termed a 'desister', or, conversely, how long an offender needs to continue offending in order to be termed a 'persister' (Chanter, 2008).

In an attempt to provide clarification, initially Maruna (2001) and later Mulvey and colleagues (2004) described desistance in terms of it being a voluntary termination of criminal offending that results in an observable and marked decrease in the frequency of offending (J-F, 2010). Moreover, this decrease in offending occurs to the extent that no further (or only negligible) involvement in crime is recorded over an extended period of time. (No clarification, however, is provided as to the length of the extended period of time). The motivation to engage in the desistance process itself typically arises out of an offender's shift 
away from self-absorption to an emergent concern for others (J-F, 2010). As such, desistance is considered to be a protracted process of untangling associations formed with offending mates and curtailing personal urges to commit crimes (J-F, 2010), even though having made a conscious decision to stop offending it is also commonplace for offenders embarking on the desistance process to continue to engage in periodic bouts of offending. Typically, though, these bouts decrease over time both in terms of their frequency and severity (Matza, 1964; Mulvey et al., 2004).

When it comes to making a theoretical distinction between a persistent and a desistant offender, Farrington (1996) suggests that persistent offenders are individuals with three or more recorded convictions. In contrast, Hagell and Newburn (1994) propose a persistent offender to be a person who has a minimum of three arrests in one year, while Soothill and colleagues (2003) argue that a persistent offender is a person with three recorded divided sentences over an eight-year period. Arnull and colleagues (2005) have proposed that a persistent offender is a young person aged 10-17 years who has been sentenced on three or more occasions for one or more recordable offence within a three-year period. More recently still, Newburn (2007) has sought to further redefine the persistent offender by delineating two persistency categories, namely the prolific-persistent offender (i.e. an offender with six or more offences within a year) and the serious-persistent offender (i.e. an offender committing a variety of offences within a 12 -month period) (J-F, 2010). Finally, recidivist offenders, who persist over time in their offending, tend to undergo a shift (i.e. displacement) in the types of crime that they commit (Massoglia, 2006). For instance, juvenile acts of antisociality or alcohol-fuelled violence are often displaced in adulthood by behaviours that require far less highrisk physical activity such as illegal drug use (J-F, 2010).

Although this preliminary body of research has been instrumental in establishing the constructs of desistance and persistence within the juvenile and adult offending populations, clearly there is a pressing need for further research, particularly in relation to comparing the desistance/persistence patterns of female offenders with those of their male offending counterparts (Piquero \& Chung, 2001). In this regard, this paper aims to extend current understanding of juvenile crime desistance/ persistence by examining the offending patterns of new entrants (graffitists) into the criminal justice system (Taylor et al., 2011). To this end, descriptive and chi-squared statistics are used to 
analyse the number of offences committed by male and female graffiti offenders $(n=667)$ in relation to the number of recorded contacts offenders had with police over a six-year recording period. The method used is described below.

\section{Method}

Upon gaining approval from the University's Human Research Ethics Committee, a research agreement was initiated with the Western Australian Police Research Unit to examine their IMS criminal offending database. The extracted de-identified data related to 41,861 offences committed by 3,751 graffiti offenders over a six-year offending period (2003-9). From the total database sample of 3,751 offenders, 575 females whose first offence was for graffiti were extracted. From these 575 females, 335 were extracted who had between 1 and 20 recorded contacts with police. A matching number of males were similarly extracted. Three of the 335 females were subsequently dropped from the study due to incomplete data.

The extracted dataset of 667 offenders ( 332 females and 335 males) included details on the type of offences committed (see Table 2) and the recorded report action taken by police. In terms of these reports, four levels of action were differentiated. The first level, Level 0, relates to reports where no recorded action was taken beyond entering the offence into the IMS database as a non-actioned offence (e.g. statute barred from prosecution, not criminally responsible, not in the public interest to proceed); the second level, Level 1, relates to report actions that were cautionary in intent (e.g. oral or written cautions); the third level, Level 2, relates to report actions that were re-directive in nature (e.g. Juvenile Justice Team [JJT] referrals); and the fourth level, Level 3, relates to report actions that were judicially oriented (e.g. summons, arrest).

In order to re-enter the dataset into PASW (formerly SPSS Statistical Package for the Social Sciences) a decision was made to delineate three categories of offender - namely, an Early Desisters category (i.e. offenders with 1-2 separately dated recorded contacts with police), a Limited Persisters category (i.e. offenders with 3-7 separately dated recorded contacts with police) and a Chronic Persisters category (i.e. offenders with 8-20 separately dated recorded contacts with police).

Furthermore, data was also categorised by age-group. In this regard, offenders were divided into three age cohorts: a preteen cohort (i.e. offenders $<13$ years at the time of their first graffiti offence), an adolescent cohort (i.e. offenders aged 13-17 years at 
the time of their first graffiti offence) and an adult cohort (i.e. offenders aged 18+ years at the time of their first graffiti offence). As it was also of interest to determine over how many years each offender's offences were committed, a value of 1,2 , $3,4,5$ or 6 for the variable 'offence year' was calculated. This allowed the calculation of the span of offending for each offender following their first graffiti offence.

Finally, in pursuit of the study's aim of investigating graffiti offenders' patterns of crime desistance/persistence, the following four research questions were devised:

1. Which age-group of graffiti offenders (preteen, adolescent, adult) commits the most crimes and comes into contact with police most frequently?

2. Which category of graffiti offenders (Early Desisters, Limited Persisters, Chronic Persisters) commits the most crimes and comes into contact with police most frequently?

3. Is gender a facet of early desistance/persistence?

4. Do age-group and category type differences exist in the start, interim and end police-recorded actions for female and male offenders?

These questions were subsequently used to guide the analysis.

\section{Results}

In response to Question 1, frequency counts of the 667 offenders revealed that at the time of their first graffiti offence their ages ranged from $10-58$ years (mean age $=14$ years). The largest agegroup was the adolescents $(n=485)$, who comprised $73 \%$ of the sample, while the preteens $(n=123)$ and the adults $(n=59)$ respectively comprised the remaining $18 \%$ and $9 \%$ (see Table 1). Moreover, as the preteens and adolescents collectively accounted for $91 \%$ of all of the offences committed, clearly graffiti-writing is predominantly a juvenile crime.

In response to Question 2, frequency count analysis revealed that the majority $(n=474,74 \%)$ of the sample's offenders were Early Desisters, $62 \%$ of whom ceased from any further offending after their initial contact with police, while the remaining $38 \%$ ceased offending after their second contact. The second largest group of offenders were the Limited Persisters $(n=144)$, and the smallest group were the Chronic Persisters $(n=29)$.

Furthermore, Table 2 reveals that while $79 \%$ of all offences committed by Early Desisters were for graffiti and property damage, the most common offences committed by Limited and 
Table 1 Frequency counts by age-group and offender type of offences and police contacts

\begin{tabular}{|c|c|c|c|c|}
\hline Age-group & Gender & $\begin{array}{l}\text { \# of } \\
\text { offenders }\end{array}$ & $\begin{array}{l}\text { \# offences } \\
\text { committed }\end{array}$ & $\begin{array}{l}\text { \# of police } \\
\text { contacts }\end{array}$ \\
\hline \multirow[t]{3}{*}{ Preteens } & & $123(18 \%)$ & $673(24 \%)$ & $371(24 \%)$ \\
\hline & Female & $57(46 \%)$ & $256(38 \%)$ & $149(40 \%)$ \\
\hline & Male & $66(54 \%)$ & $417(62 \%)$ & $222(60 \%)$ \\
\hline \multirow[t]{3}{*}{ Adolescents } & & $485(73 \%)$ & $1,948(69 \%)$ & $1,086(69 \%)$ \\
\hline & Female & $246(51 \%)$ & $907(47 \%)$ & $530(49 \%)$ \\
\hline & Male & $239(49 \%)$ & $1,041(53 \%)$ & $556(51 \%)$ \\
\hline \multirow[t]{4}{*}{ Adults } & & $59(9 \%)$ & $187(7 \%)$ & $108(7 \%)$ \\
\hline & Female & $29(49 \%)$ & $128(68 \%)$ & $68(63 \%)$ \\
\hline & Male & $30(51 \%)$ & $59(32 \%)$ & $40(37 \%)$ \\
\hline & Total & 667 & 2,808 & 1,565 \\
\hline Offending type & Age-group & $\begin{array}{l}\text { \# of } \\
\text { offenders }\end{array}$ & $\begin{array}{l}\text { \# offences } \\
\text { committed }\end{array}$ & $\begin{array}{l}\text { \# of police } \\
\text { contacts }\end{array}$ \\
\hline \multirow[t]{4}{*}{ Early Desisters } & & $494(74 \%)$ & $798(28 \%)$ & $585(38 \%)$ \\
\hline & Preteens & $87(18 \%)$ & $136(17 \%)$ & $107(18 \%)$ \\
\hline & Adolescents & $360(73 \%)$ & $575(72 \%)$ & $426(73 \%)$ \\
\hline & Adults & $47(9 \%)$ & $87(11 \%)$ & $52(9 \%)$ \\
\hline \multirow[t]{4}{*}{ Limited Persisters } & & $144(22 \%)$ & $1,232(44 \%)$ & $631(40 \%)$ \\
\hline & Preteens & $23(16 \%)$ & $192(16 \%)$ & $106(17 \%)$ \\
\hline & Adolescents & $110(76 \%)$ & $954(77 \%)$ & $477(76 \%)$ \\
\hline & Adults & $11(8 \%)$ & $86(7 \%)$ & $48(7 \%)$ \\
\hline \multirow[t]{5}{*}{ Chronic Persisters } & & $29(4 \%)$ & $778(28 \%)$ & $349(22 \%)$ \\
\hline & Preteens & $13(45 \%)$ & $345(44 \%)$ & $158(45 \%)$ \\
\hline & Adolescents & $15(52 \%)$ & $419(54 \%)$ & $183(53 \%)$ \\
\hline & Adults & $1(3 \%)$ & $14(2 \%)$ & $8(2 \%)$ \\
\hline & Total & 667 & 2,808 & 1,565 \\
\hline
\end{tabular}

Chronic Persisters were assault, burglary and theft. Moreover, as can be seen from the shaded offence lines in Table 2, Limited Persisters committed 298 (67\%) of the total 446 recorded violent offences. In addition, chi-squared analysis reveals a significant association between the type of offence (violent, non-violent) and whether the perpetrators were Early Desisters, Limited Persisters or Chronic Persisters $\left\{\mathrm{x}^{2}=150.01\right.$ (2), $\left.\mathrm{p}=.0001\right\}$.

In response to Question 3, Table 1 reveals that the majority of male offenders started their offending during adolescence. In addition, chi-squared analysis reveals a significant association 


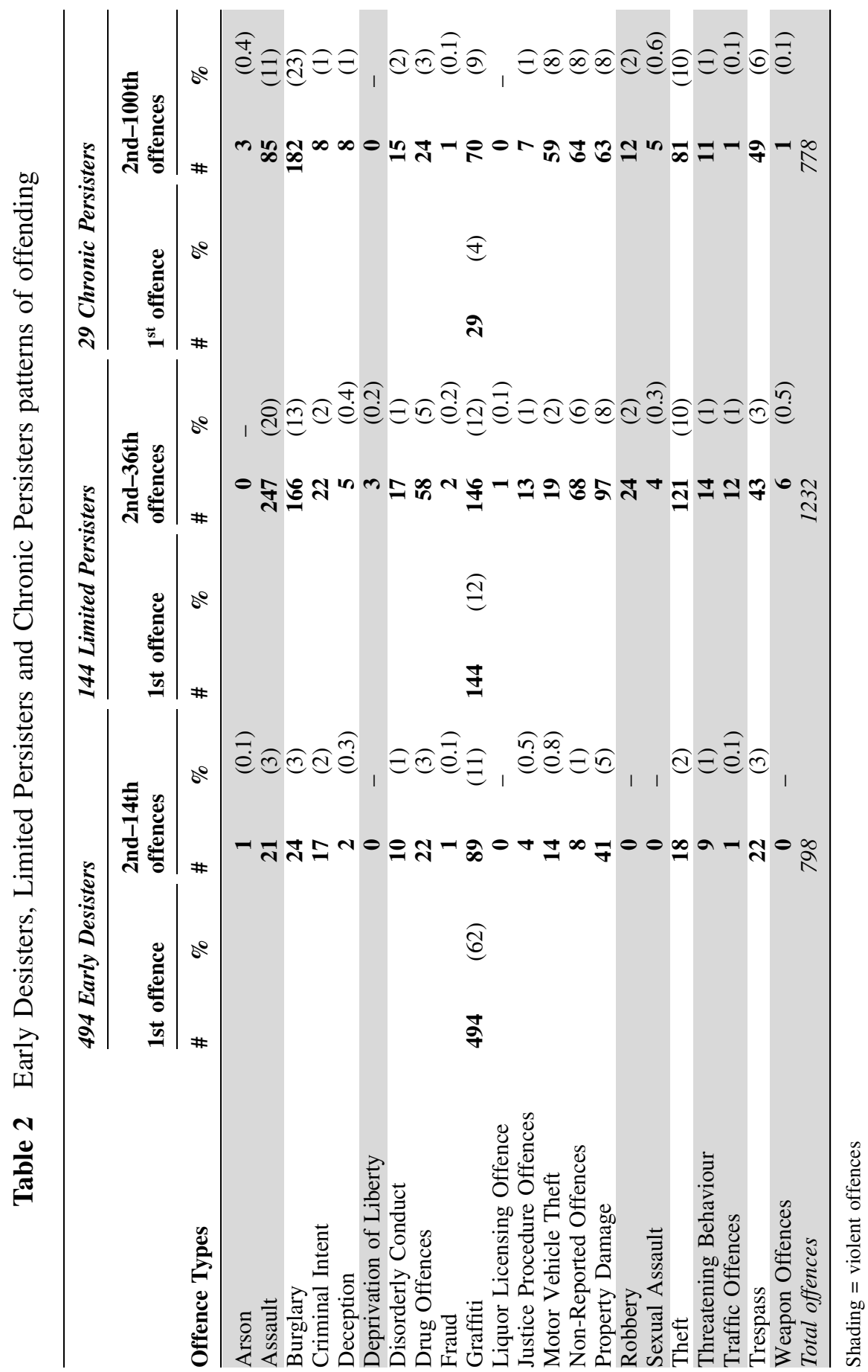


between gender and the number of contacts with police $\left\{x^{2}=19.06(2), p=.0001\right\}$, and gender and the number of offences committed $\left\{\mathrm{x}^{2}=55.36(2), \mathrm{p}=.0001\right\}$. It is also apparent from Table 1 that male offenders who began offending in their preteen years tend to commit more offences and have more contacts with police than do their preteen female offending age-mates. In contrast, female graffitists who commence their graffiti offending as an adult, commit offences and come into contact with police at a rate nearly double that of their adult male counterparts. In terms of the length of time of offending, frequency count analysis revealed that 229 females and 242 males had a 1-year offending span; 40 females and 39 males had a 2-year offending span; 37 females and 24 males had a 3-year offending span; 16 females and 23 males had a 4-year offending span; 9 females and 5 males had a 5-year offending span and 1 female and 2 males had a 6-year offending span.

Figure 1 provides a visual illustration of gender differences in the levels of police report action for offences committed by Early Desisters ( $n=389$ female and 409 male offences), Limited Persisters ( $n=695$ female and 537 male offences) and Chronic Persisters ( $n=207$ female and 571 male offences). Chi-squared analysis additionally reveals no association between gender and levels of police report action among female and male Early Desisters and Limited Persisters. However, an association is evident between gender and levels of police report action among female and male Chronic Persisters $\left\{\mathrm{x}^{2}=19.22(2), \mathrm{p}=.0001\right\}$.

Finally, in response to Question 4, Table 3 provides the statistical means of the number of offences, and the number of contacts with police, had by female and male Early Desisters, Limited Persisters and Chronic Persisters per age-group. An increasing trend pattern is evident within each of the three agegroups, insofar as the lowest mean number of recorded offences (i.e. preteens: female 1.71 - male 1.43; adolescents: female 1.56 - male 1.64; and adults: female 2.05 - male 1.71) and the lowest mean number of recorded contacts with police (i.e. preteens: female 1.22 - male 1.24; adolescents: female 1.20 - male 1.17; and adults: female 1.11 - male 1.11) occur within the Early Desisters offending category; and the highest mean number of recorded offences (i.e. preteens: female 23.50 - male 27.89; adolescents: female 19.80 - male 32.00; and adults: female 14.00 - male 5.50) and the highest mean number of recorded contacts with police (i.e. preteens: female 12.75 - male 11.89; adolescents: female 10.40 - male 13.10; and adults: female 


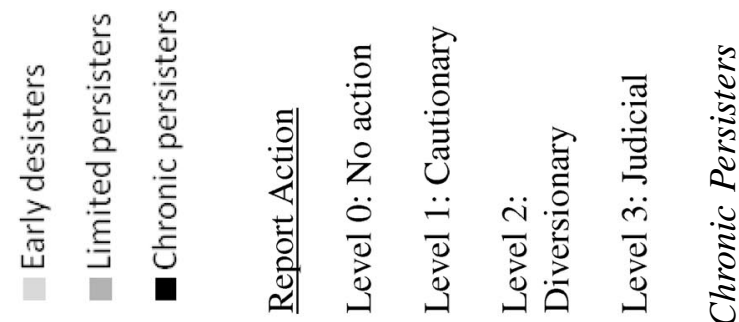

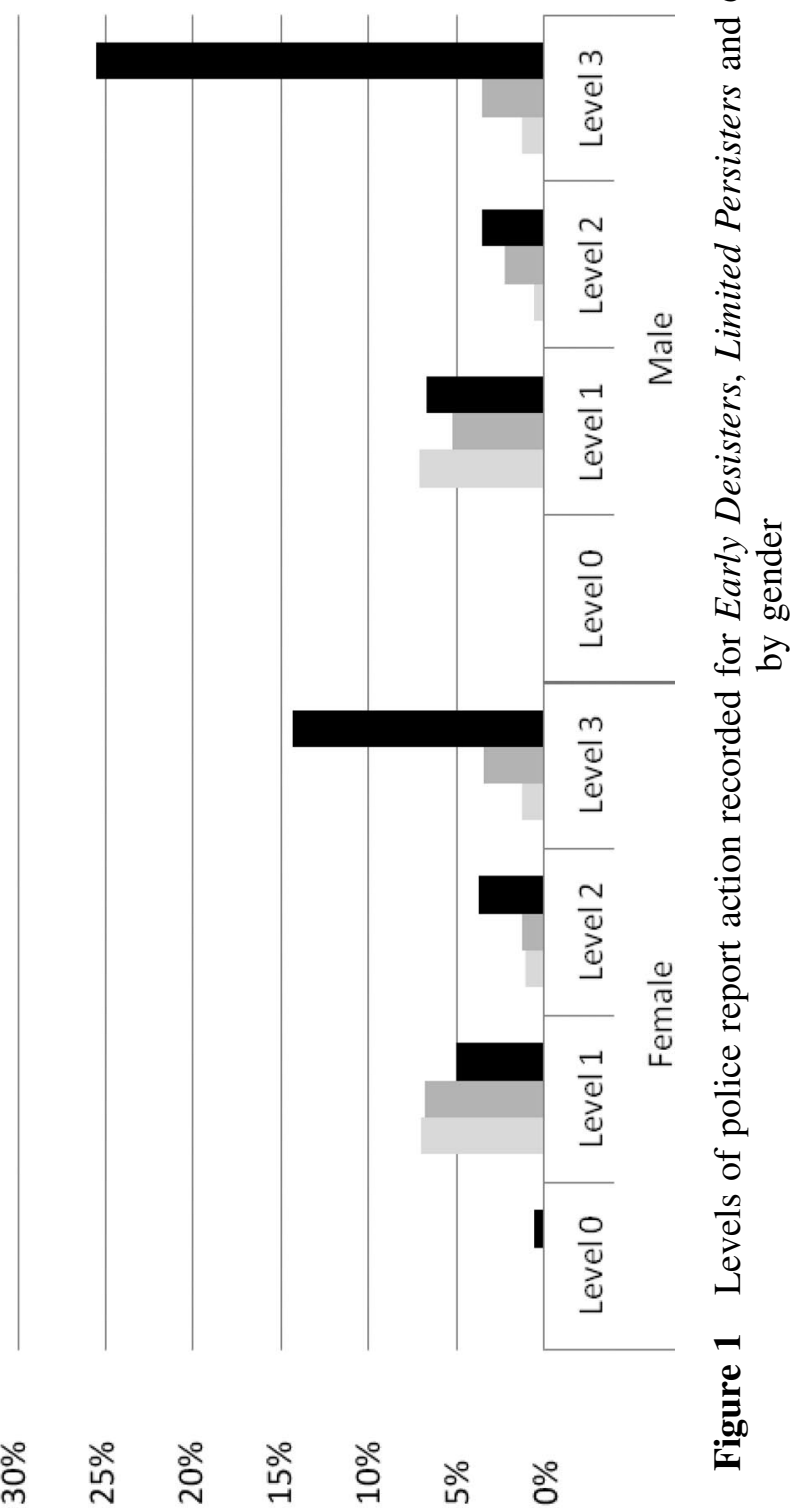




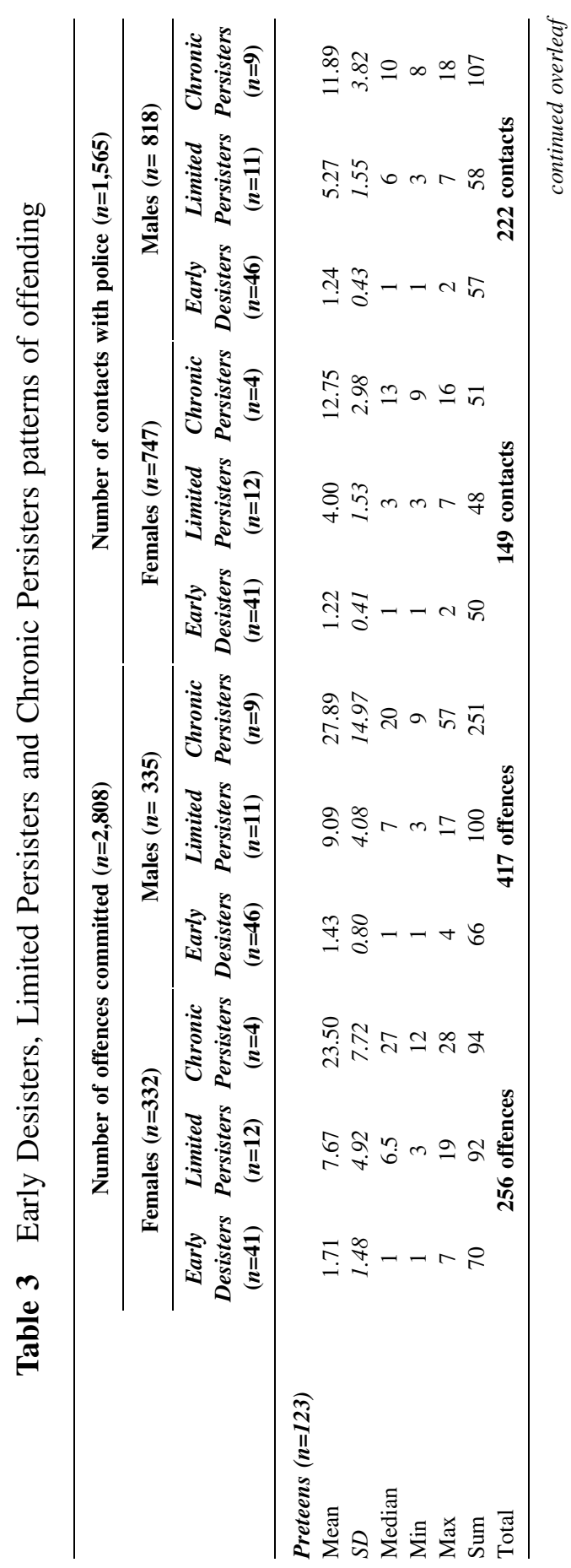

The Police Journal, Volume 85 (2012) 


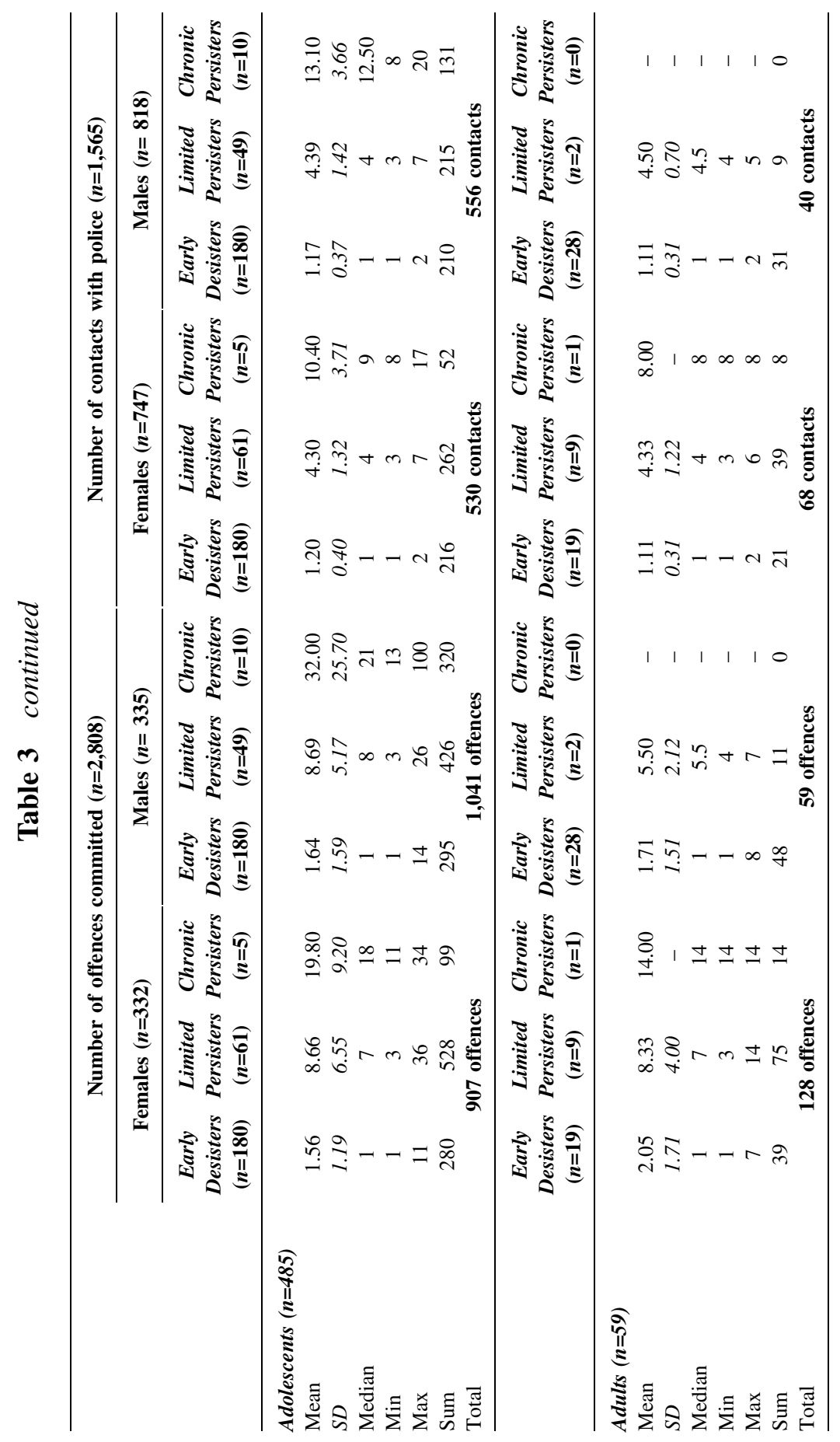


8.00 - male 4.50) occur within the Chronic Persisters offending category.

Figure 2 provides a visual illustration of age-group differences in the levels of police report actions for offences committed by Early Desisters $(n=136$ preteen, 575 adolescent and 87 adult offences), Limited Persisters ( $n=192$ preteen, 954 adolescent and 86 adult offences) and Chronic Persisters ( $n=345$ preteen, 419 adolescent and 14 adult offences). Chi-squared analysis reveals an association between age-group and levels of police report actions among preteen, adolescent and adult Early Desisters $\left\{\mathrm{x}^{2}=362.6(4), \mathrm{p}=.0001\right\}$ and among preteen, adolescent and adult Limited Persisters $\left\{\mathrm{x}^{2}=334.56(4), \mathrm{p}=.0001\right\}$.

To determine Early Desisters', Limited Persisters' and Chronic Persisters' interim levels of offending within all three age-groups, a further frequency count was conducted of all offences committed in the interim period between the offenders' first and last offences. For example, an interim offence for Early Desisters would be any additional offence entered into the database after their first recorded (start) offence and before their last recorded (end) offence that occurred either at the time of their first point of contact with police or at their second point of contact with police. Similarly, an interim offence for Limited Persisters would be any additional offence entered into the database after their first recorded (start) offence and before their last recorded (end) offence that occurred any time between their first and seventh point of contact with police. For Chronic Persisters interim offences would be any additional offence entered into the database after their first recorded (start) offence and before their last recorded (end) offence that occurred at any time between their first and twentieth contact with police.

Figure 3, comprising nine mini-graphs, displays a comparison analysis of the three age-groups and the three categories of offenders' start, interim and end levels of offence action recorded by police. The three preteen age-group graphs and the three adolescent graphs reveal that the majority of all juvenile offenders typically attract a caution for their initial (start) offence of graffiti (i.e. preteens: Early Desisters 92\%, Limited Persisters 100\% and Chronic Persisters 77\%; adolescents: Early Desisters 82\%, Limited Persisters $75 \%$ and Chronic Persisters 73\%). In contrast, the start, interim and end adult offender graphs reveal that nearly all adults received a Level 3 report action not only for their initial graffiti offence but also for their interim and end offences. 


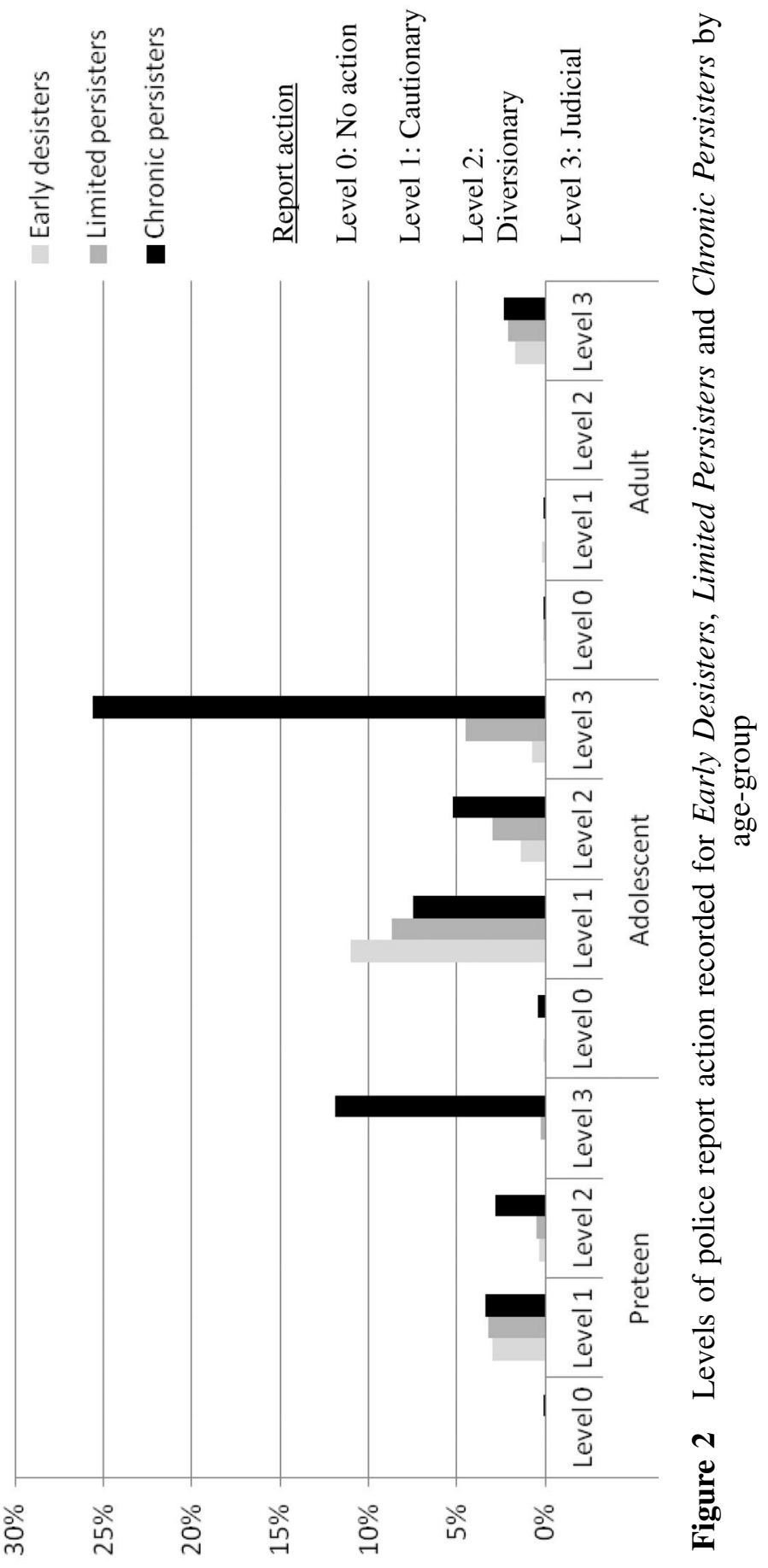




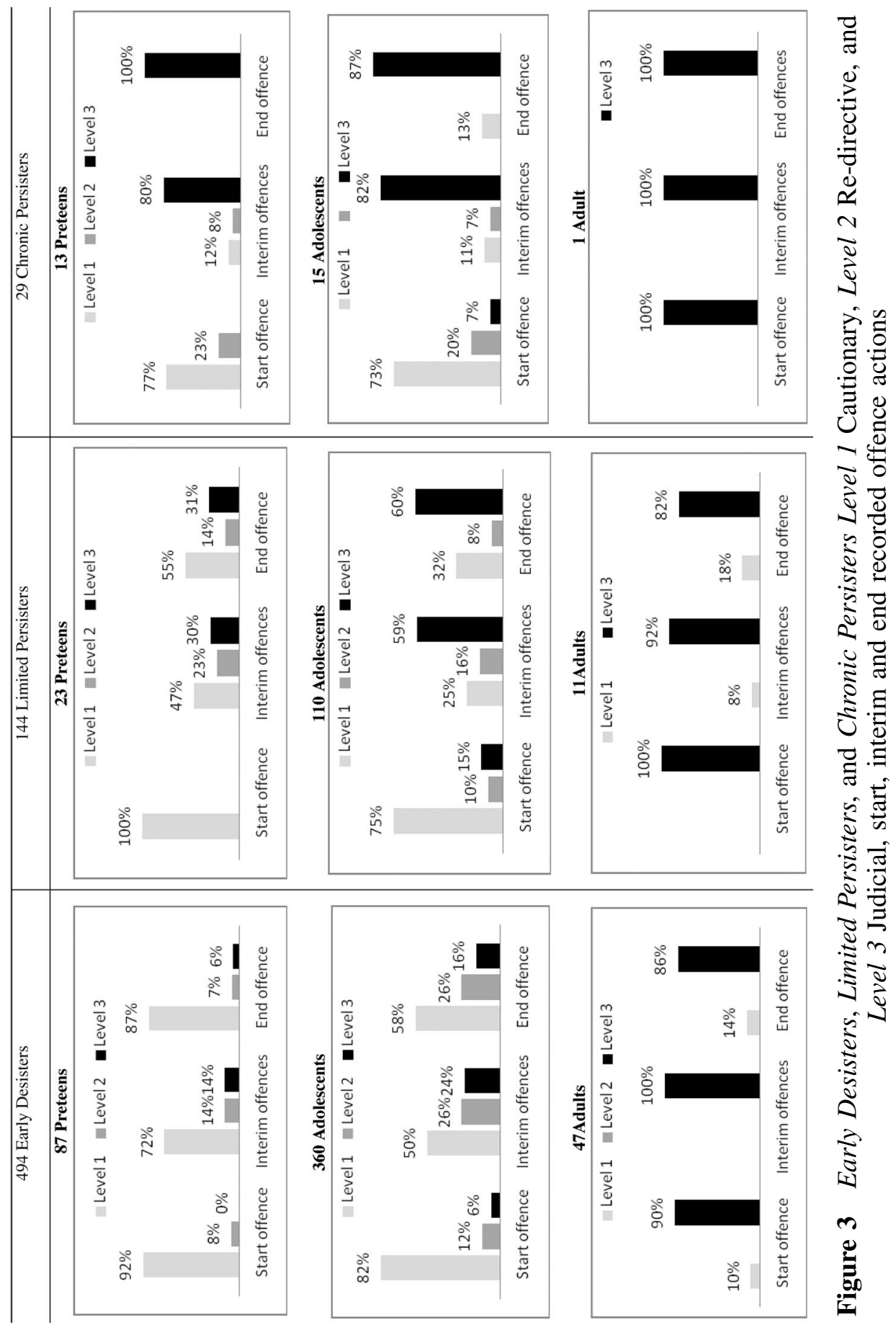

The Police Journal, Volume 85 (2012) 
In addition, Figure 3 also reveals that preteen Early Desisters are more likely to receive a Level 1 caution for their interim offences than they are to receive either a Level 2 re-directive referral to JJT (Juvenile Justice Team) or a Level 3 judicial report action. However, the likelihood of preteen Chronic Persisters receiving a Level 1 cautionary interim report action was poor, as $80 \%$ of preteen Chronic Persisters' interim offences and $100 \%$ of their end offences were a Level 3 judicial interim report action. In contrast, adolescent Early Desisters had a 50\% likelihood of a Level 1 interim caution, Limited Persisters a 25\% likelihood and Chronic Persisters a 11\% likelihood. Similarly, the likelihood of a Level 2 interim re-directive JJT referral report action decreased from $26 \%$ for adolescent Early Desisters to $16 \%$ for adolescent Limited Persisters, and to $7 \%$ for adolescent Chronic Persisters. This decreasing trend was reversed when it came to the likelihood of receiving a Level 3 interim judicially oriented report action, as the likelihood rose from $24 \%$ for adolescent Early Desisters to 59\% for adolescent Limited Persisters, and to $82 \%$ for adolescent Chronic Persisters.

Finally, Figure 3 reveals that only preteen Early Desisters, preteen Limited Persisters and adolescent Early Desisters had a greater than 50\% likelihood of receiving a Level 1 cautionary report action for their final (end) offence, while all of the remaining age-group categories had a $60 \%$ or greater likelihood of receiving a Level 3 judicial report action for their final (end) offence.

\section{Discussion}

Much is expected of the various arms of the police and justice system. On the one hand they are charged with keeping communities safe and with ensuring that responses to crime are proportionate to the offences committed, while on the other hand they are charged with the task of keeping offenders' longer-term best interests in mind (Mulvey et al., 2004). In relation to juvenile offenders, one of the problems facing police and the Juvenile Justice System is that there is only a comparatively small pool of empirical desistance/persistence research literature relating specifically to juveniles to which they can refer. As a consequence, Mulvey and colleagues suggest that adolescent offenders are typically processed and handled using commonsense guidelines that have been developed over a number of years based on repeated policy procedures and practice reviews. 
In the context of Western Australia, newly offending juveniles who are processed for relatively 'minor' crimes typically receive cautions or are redirected into diversionary programmes while their more persistent offending peers are processed through the court system. Mulder and colleagues (2010) support the use of such an approach as it distinguishes between the differing needs of novice and prolific juvenile offenders. Indeed, they specifically caution against viewing/treating all juvenile offenders as a single homogeneous entity, claiming that different categories of juvenile offender have very different static and dynamic risk factors for re-offending.

Interestingly, though, not all young people who appear to be at high risk for engaging in lifelong criminal offending actually proceed along that pathway. Whilst some theorists such as Moffitt (1993) suggest most adolescents 'age out of' crime, there are other theorists who note that other at-risk juveniles, despite experiencing considerable personal adversity, are able to draw on a number of personal, family and community resilience factors to alter or halt their likely trajectory towards life-course offending. Indeed, it is hypothesised that it is the offender's personal resilience quotient that is key to their receptiveness and progressive engagement in intervention programmes (Cottle et al., 2001). Typically, personal resilience includes such attributes as critical mindedness, agentic engagement, flexibility and communal collectivism (Unger, 2010; 2011).

The results of the present study reveal that almost threequarters of preteen, adolescent and adult graffiti offenders seemingly desist from further offending after only their first or second contact with police. Clearly, further qualitative research studies are needed to elicit from early desistant graffiti offenders how they utilised their resilience attributes to reach a decision to cease offending. The results of such studies will increase the understanding of the role that police, family and youth intervention programmes play in the novice offender's decisionmaking.

A second result from the present study which has application relevance to reducing recidivist offending is the revelation that two-thirds of the offences committed by Limited Persisters are violent offences. It is posited by Deuchar (2009) that collective involvement in violent activities by groups of young persistent offenders not only provides them with stocks of compensatory social capital, but also leads to the ready assimilation of their youth street culture's social norms. Clearly, further research is needed to ascertain greater insights from this offending youth 
cohort as to why, when and how the transition from non-violent to violent offending occurs. The value of such research is that it could inform the design of intervention programmes (e.g. for anger management, social inclusion, etc.) targeted at the transitioning cohort of pre-violent offending adolescent.

Certainly, Mulvey and colleagues (2004) have long suggested that interventional initiatives aimed at reducing juvenile recidivist offending need to be informed by the changing personal social capital needs of offenders and of the social climate in which they live and operate. This need, along with a greater understanding of the factors which contribute to resilience building in novice offenders, is predicated on the realisation that the present tendency to employ progressively harsh and punitive approaches to dealing with juvenile offenders is not necessarily producing the desired social outcome, namely, offending cessation (see Carroll et al., 2009; Deuchar, 2009; Taylor et al., 2010). For example, the Western Australian practice of punitively progressing novice, intermediate and seasoned graffiti offenders through the court system for their offences has not, in many instances, ceased their offending. Indeed, it would seem that the practice of awarding increasingly severe punishments has resulted in some unintended outcomes. For instance, the recently enacted Western Australian measure of 'banning' juvenile graffitists from the site of their graffiti offending (e.g. shopping centre, public transport system) has not become the desistance catalyst it was intended to be, primarily, it seems, because the banning measure has in some instances oriented the banned offender towards the company of their more prolific offending age-mates. Moreover, this association is placing novice offenders on a trajectory towards more serious and persistent offending (Taylor et al., 2011). Anecdotal accounts from graffiti offenders reveal that the act of being banned is providing banned individuals with an elevated level of street kudos (non-conforming social notoriety) (see Taylor et al., 2010). In turn, this elevation is producing two further unintended consequences. First, unless the underlying offending dynamic causal needs of the banned novice offender (potential Early Desisters) are met, then the now 'noticed' novice is likely to be attracted towards taking up the ensuing invitations to join established graffiti crews that notoriety often brings. Once inducted into a crew, the banned novice offender receives encouragement and opportunity to 'get up' (i.e. place their tag or have it placed in positions of high visual prominence) from the crew's members. Continued association with crew members 
invariably leads to recidivist offending and the banned individual seemingly moves into the realm of the Limited Persister offender. Second, the camaraderie and social recognition within the graffiti community that increased notoriety brings is addictive (Taylor, 2012). Continued involvement in the subculture and repeated engagements in escalating graffiti-related offences (i.e. property damage, theft, assaults) ultimately provides the banned individual with the highly prized 'graffer' social identity and a sense of belonging, purpose and protection. Once gained, maintenance of one's recognitional status among the graffiti subculture requires a commitment to the graffiti lifestyle. In this regard, those graffitists who are bent upon maintaining a subculture reputation characteristically tend to become society's long-term persistent offenders (Taylor et al., 2010).

High recidivism rates (Bureau of Justice Statistics, 2002) among chronically persisting offenders have led some criminologists to question whether incarcerating juveniles in the early stages of their offending is a cost-effective means of dealing with recidivism (Farrall, 2004; Allen, 2006; Chanter, 2008; J-F, 2010; Palermo, 2009). It has been further posited that the implementation of increasingly harsh punitive punishments for relatively minor offences is setting young offenders up for 'failure' (Carrington \& Schulenberg, 2003). Other criminologists still caution that the move towards popular punitivism can allow the public/ media's retributional views to supersede the fundamental rehabilitation needs of juvenile offenders. Concerns have also been raised about the practice of juvenile detention/incarceration, claiming that it has the potential to interrupt normal child/ adolescent developmental processes, reinforce delinquent attitudes and create the ingredients for bullying and racist behaviours in the future (Garland, 2001; Shulenberg, 2003; Allen, 2006).

Other researchers such as Halsey \& Young (2006) have gone as far as to suggest that society's current response to juvenile graffiti crime is largely ungovernable and that new approaches to desistance need to be considered. In light of the present study's finding that approximately $75 \%$ of all novice offenders desist from any further offending after their first or second contact with police, it is the authors' contention that more research is needed to better understand what is happening in the lives of these Early Desisting offenders, the reasoning being that if such an understanding is developed it is likely to hold three important societal benefits. First, it will help to provide an understanding of the support systems young people say they need in order to live 
crime-free lives. Second, it will allow these identified support 'needs' to be incorporated into crime prevention and youth diversion programmes, and third, it will allow for the better tailoring of individualised programmes for offenders caught in the loop of wanting to desist from offending, but yet still continuing with their offending because they lack internal motivation and positive external supports.

\section{Limitations of the study}

While the presented study provides valuable insights into graffiti offenders' desistance/persistence patterns of offending, it must be noted that the research has a number of limitations. First, there are no universal measures for youth desistance/persistence and so the study's three offending type divisions (i.e. Early Desisters, Limited Persisters and Chronic Persisters) are pertinent to this study only. Second, given that up to $98 \%$ of all juvenile delinquent offending never appears on police databases (Carroll et al., 2008; Friendship et al., 2002), analysis of police datasets can only be considered as a partial indicator of increased/decreased recidivist offending. Third, the use of proxy measures of offending desistance/persistence (e.g. police databases) can distort the true patterns of desistance/persistence among offenders, as recidivist offenders tend to learn from their prior apprehension experiences and then tend to engage in covert, less detectable types of offence, which can result in a false assessment that their offending patterns have ceased/ decreased (Cuneen \& Luke, 2007; Hedderman, 2009; Tresidder et al., 2009; J-F, 2010). Fourth, while the police report data might provide indicative desistant and persistent patterns of offending, they might also be reflective of other extraneous factors, such as offenders committing less detectable offences and changes in the processing practices of offenders (Richards, 2011).

\section{References}

Allen, R. (2006) From punishment to problem solving; A new approach to children in trouble. London: Centre for Crime and Justice Studies.

Arnull, E., Eagle, S. and Gammampila, A. (2005) Persistent Young Offenders - A retrospective study. London: Youth Justice Board for England and Wales.

Bersani, B.E., Nieuwbeerta, P. and Laub, J.H. (2009) 'Predicting trajectories of offending over the life course: Findings from a Dutch conviction cohort' Journal of Research in Crime and Delinquency 46: 468-94. 
Bureau of Justice Statistics. (2002) Re-entry trends in the U.S. recidiv ism. Available at: <http://www.ojp.usdoj.gov/bjs/reentry/recidiv ism.htm>.

Carrington, P.J. and Schulenberg, J.L. (2003) Police discretion with young offenders. Ottawa, ON: Department of Justice Canada.

Carroll, A.M., Houghton, S., Durkin, K. and Hattie, J. (2009) Adolescent reputations and risk: Developmental trajectories to delinquency. Bloomington, IN: Springer.

Carroll, A.M., Houghton, S., Khan, U. and Tan, C. (2008) 'Delinquency and reputational orientations of adolescent at-risk and notat-risk males and females' Educational Psychology 28: 777-93.

Chanter, A. (2008) Persistent young offender's future: A view from inside the hood. Proceedings from the Plymouth Postgraduate Symposium 2008. Available at: <http://www.plymouth.ac.uk/files/ extranet/docs/SSB/PPGS\%202008\%20Final\%20Publication\%20 (Final $\% 20$ Complete).pdf\#page $=9>$.

Cohen, M.A., Piquero, A.R. and Jennings, W.G. (2010) 'Studying the costs of crime across offender trajectories' Criminology \& Public Policy 9: 280-305.

Cottle, C.C., Lee, R.J. and Heilbrun, K. (2001) 'The prediction of criminal recidivism in juveniles' Criminal Justice and Behavior 28: 367-94.

Cuneen, C. and Luke, G. (2007) 'Recidivism and the effectiveness of criminal justice interventions: Juvenile offenders and post release support' Current Issues in Criminal Justice 19: 197-210.

Deuchar, R. (2009) Gangs, Marginalised Youth and Social Capital. Stoke-on-Trent: Trentham.

Farrall, S. (2004) Rethinking what works with offenders: Probation, social context and desistance from crime. Cullompton: Willan Publishing.

Farrington, D.P. (1996) Understanding and preventing youth crime. York: York Publishing Services Ltd.

Fergusson, D.M. and Horwood, L.J. (2002) 'Male and female offending trajectories' Development and Psychopathology 14: 159-77.

Fontaine, N., Carbonneau, R., Vitaro, F., Barker, E.D. and Tremblay, R.E. (2009) 'Research review: A critical review on studies on the developmental trajectories of antisocial behaviour in females' Journal of Child Psychology and Psychiatry 50: 363-85.

Francis, B., Liu, J. and Soothill, K. (2010) 'Criminal lifestyle specialization: Female offending in England and Wales' International Criminal Justice Review 20: 188-204.

Friendship, C., Beech, A. and Browne, A. (2002) 'Reconviction as an outcome measure in research: A methodological note' British Journal of Criminology 42: 443-4.

Garland, D. (2001) The culture of control. Oxford: Oxford University Press.

Gottfredson, R.M. and Hirschi, T. (1990) A general theory of crime. Stanford, CA: Stanford University Press. 
Hagell, A. and Newburn, T. (1994) Persistent young offenders. London: Policy Studies Institute.

Halsey, M. and Young, A. (2006) 'Our desires are ungovernable: Writing graffiti in urban space' Theoretical Criminology 10: 275-306.

Hedderman, C. (2009) 'How not to assess probation performance. Constructing local reconviction rates' Probation Journal 56: 111-27.

Henry, B., Caspi, A., Moffitt, T.E. and Silva, P.A. (1996) 'Temperamental and familial predictors of violent and non-violent criminal convictions: Ages 3 to 18' Developmental Psychology 32: 614-23.

J-F. (2010) Ex-inmates living crime-free: A phenomenological study. Unpublished doctoral thesis. University of Queensland, Australia.

Laub, J.H. and Sampson, R.J. (2003) Shared beginnings, divergent lives: Delinquent boys to age 70. Cambridge, MA: Harvard University Press.

Loeber, R., Slot, N.W. and Sergeant, J.A. (2001) Ernstige en gewelddadige jeugddelinquentie: Omvang, oorzaken en interventies [Serious and violent juvenile delinquency: Extent, causes and interventions]. Houten, The Netherlands: Bohn Stafleu Van Loghum.

Loeber, R., Wung, P., Keenan, K., Giroux, B., Stouthamer-Loeber, M. and van Kammen (1993) 'Developmental pathways in disruptive child behavior' Development and Psychopathology 5: 101-32.

Maruna, S. (2001) Making good: How ex-convicts reform and rebuild their lives. Washington, DC: American Psychological Association.

Massoglia, M. (2006) 'Desistance or displacement? The changing patterns of offending from adolescence to young adulthood' Journal of Quantitative Criminology 22: 215-39.

Matza, D. (1964) Delinquency and drift. New York: John Wiley.

Mazerolle, P., Piquero, A.R. and Brame, R. (2010) 'Violent onset offenders: Do initial experiences shape criminal career dimensions?' International Criminal Justice Review 20: 132-46.

Moffitt, T.E. (1993) 'Adolescence-limited and life-course-persistent antisocial behaviour: A developmental taxonomy' Psychological Review 100: 674-701.

Moffitt, T.E. (2003) 'Life-course persistent and adolescent limited antisocial behaviour: A 10 year research review and a research agenda' in Lahey, B.B., Moffitt, T.E. and Caspi, A. (eds), Causes of conduct disorder and juvenile delinquency. New York: Guilford Press.

Moffitt, T.E. (2006) 'A review of research on the taxonomy of lifecourse persistent versus adolescence-limited antisocial behaviour' in Cullen, F.T., Wright, J.P. and Blevins K.R. (eds.), Taking stock: The status of criminology theory. New Brunswick, NY: Transaction Publishers, 277-322. 
Mulder, E., Brand, E., Bullens, R. and van Marle, H. (2010) 'A classification of risk factors in serious juvenile offenders and the relation between patterns of risk factors and recidivism' Criminal Behaviour and Mental Health 20: 23-38.

Mulder, E., Brand, E., Bullens, R. and van Marle, H. (2011) 'Risk factors for overall recidivism and severity of recidivism in serious offenders' International Journal of Offender Therapy and Comparative Criminology 55: 118-35.

Mulvey, E.P., Steinberg, L., Hecker, T., Fagan, J., Cauffman, E., Schubert, C., Piquero, A., Losoya, S., Chassin, L., Knight, G. and Brame, R. (2004) 'Theory and research on desistance from antisocial activity among adolescent serious offenders' Youth Violence and Juvenile Justice 2: 213-36.

Muncie, J. (2004) Youth and crime. London: Sage.

Newburn, T. (2007) Criminology. Cullompton: Willan Publishing.

Odgers, C.L., Moretti, M.M., Burnette, M.L., Chauhan, P., Waite, D. and Reppucci, N.D. (2007) 'A latent variable modeling approach to identifying subtypes of serious and violent female juvenile offenders' Aggressive Behaviour 33: 339-52.

Palermo, G.B. (2009) 'Reintegration and recidivism' International Journal of Offender Therapy and Comparative Criminology 53: 3-4.

Piquero, A.R. (2008) 'Taking stock of developmental trajectories of criminal activity over the life course' in Liberman, A. (ed.), The long view of crime: A synthesis of longitudinal research. New York: Springer.

Piquero, A.R. and Chung, H.L. (2001) 'On the relationships between gender, early onset, and the seriousness of offending' Journal of Criminal Justice 29: 189-206.

Richards, K. (2011) Technical and background paper: Measuring juvenile recidivism in Australia. Canberra: Australian Institute of Criminology.

Roe, S. and Ashe, J. (2008) Young people and crime: Findings from the 2006 offending, crime and justice survey. Available at: http://rds. homeoffice.gov.uk/rds/pdfs08/hosb0908.pdf

Schulenberg, J.L. (2003) 'The social context of Police discretion with young offenders: An ecological analysis' Canadian Journal of Criminology and Criminal Justice 45: 127-57.

Soothill, S., Ackerlet, E. and Francis, B. (2003) 'The persistent offenders debate in criminal justice' International Journal of Policy and Practice 3: 389-414.

Stuewig, J. (2000) Factors related to the desistance of crime in a longitudinal sample. University of Arizona, Tucson.

Taylor, M.F. (2012) 'Addicted to the risk, recognition and respect that the graffiti lifestyle provides: Towards an understanding of the reasons for graffiti engagement' International Journal of Mental Health and Addiction 10: 54-68. 
Taylor, M.F., Houghton, S. and Bednall, J. (2010) Friendships, peer socialization and social identity among adolescent skateboarders and graffiti writers. New York: Nova Science Publishers, Inc.

Taylor, M.F., Marais, I. and Cottman, R. (2011) 'Western Australian preteen, adolescent and adult patterns of graffiti offending: Towards recognition that graffiti offending is more than "kids messing around"' Policing and Society: An International Journal of Research and Policy. Available at: http://dx.doi.org/10.1080/1043 9463.2011.605128

Tresidder, J., Payne, J. and Homel, P. (2009) Measuring youth justice outcomes. Canberra: Australian Institute of Criminology.

Unger, M. (2010) 'Families as navigators and negotiators: Facilitating cultural and contextually specific expressions of resilience' Family Process 49: 421-36.

Unger, M. (2011) 'The social ecology of resilience: Addressing contextual and cultural ambiguity of a nascent construct' American Journal of Orthopsychiatry 81: 1-17. 